\title{
NEW THYRIDIDAE IN THE TRING MUSEUM.
}

\author{
By W. WARREN, M.A., F.E.S.
}

1. Addaea castaneata spec. nov.

Forewing: with basal area, a broad median fascia, and the whole marginal area deep chestuut-brown, with slightly darker transverse striae especially along costa; a violet purplish tinge along submedian interspace; the median fascia is slightly oblique, narrow at costa, swollen a little above the median vein and bulged below it: on each side of it is a whitish oblique band, the inner one narrow and the outer wide, with some grey strigae in their centre; fringe brown, blackish at apex and anal angle.

Hindwing: similar; in the marginal brown area there appears a narrow submarginal band, which is slightly visible on forewing as well ; fringe blackish towards apex only.

Underside similar, the contrast greater between the pale and dark areas.

Head, thorax, and abdomen all brown.

Expanse of wings : $20 \mathrm{~mm}$.

2 ठิठ from Milne Bay, British New Gninea, January and February 1899 (Meek).

Allied to both polyphoralis Wlk. and pusilla Butler, but entirely distinct from either.

\section{Banisia angustifascia Warr.}

In Nov. Zool. vi. p. 315 (1899) I suggested that my B. angustifascia $q$ from Amboina was the same species as $B$. multifenestrata of Warr. from Humboldt Bay, New Guinea. This identification was premature. For though angustifascia occurs commonly in New Guinea, also in the Kei Islands and the Louisiades, yet a good series of both sexes shows that its real $\delta$ is much more like the $f$ than multifenestrata. The sexes agree in having the apical area of forewing filled up with dark fuscous, a; in Pagenstecher's nitida; but in place of the numerous whitish hyaline spaces which appear in multifenestrata, the $\delta$ of angustifascia has normally four square white spots in forewing and two in the hindwing; the two most prominent are placed, in the forewing, one above the other on each side of vein 2 between the two branches of the postmedian fascia, the other two being on the innerside of the inner branch, but the upper one of the latter pair is very small and often obsolete; in the hindwing the two spots are always above vein 2 , one on each side of the inner branch of fascia. In multifenestrata $\delta$ the apex of forewing is of the ground colour, and there are some irregular black spots before outer margin above the middle ; at present no $f$ of this form has appeared, though an additional $\delta$ from the Kumusi River has been sent, exactly like the original 2 o $\delta$ from Humboldt Bay.

3. Banisia funesta spec. nov.

Forewing: glossy blackish fuscous with a slight olive tinge; the bands, which are slightly darker than the rest of wing, are placed almost exactly as in B. angustifascia Warr. 
Hindwing: the same.

Underside pale pearl-grey, with the reticnlations olive-fuscous; the costal and apical areas of forewing are usnally browner.

Head, thorax, and abdomen all blackish, like wings.

Expanse of wings : $\delta 32 \mathrm{~mm}$. ; $q 36 \mathrm{~mm}$.

$2 \delta \delta, 2 q q$ from Biagi, Mambaré River, British New Guinea, 5,000 feet, April 1906 (A. S. Meek).

Distingnished from all the forms whose $\delta \delta$ have hyaline spots or patches in the wings by the $\delta \delta$ being as densely clothed as the $q q$.

\section{Banisia illustrata spec. nov.}

Forewing: semi-transparent ochreous, the veins and reticulations rufous; the costa broadly, inner margin below vein 1, and nearly the basal half of wing chocolate-brown; a slight oval pale space on submedian interval within the brown area; from the costal streak beyond middle two irregular teeth give rise to brown lines; that from the onter tooth running to below middle of outer margin and above vein 5 emitting a spur to meet one from the inner tooth; from their junction a brown line runs to an oblong brown bloteh at anal angle: from the inner tooth another line runs to a similar blotch at two-thirds of inner margin; fringe ocbreous, chequered with brown.

Hindwing: with three narrow interrupted and ramifying brown bands, the second ending in a large blotch beyond middle of inner margin, the third forking to anal angle and outer margin ; apical area brown to middle of outer margin.

Underside much paler; costa of forewing pale chocolate-brown ; the antemedian and postmedian fasciae of forewing in their lower halves, and the costal streaks of hindwing rich black-brown.

Head, thorax, and abdomen all chocolate-brown.

Expanse of wings : $35 \mathrm{~mm}$.

1. + from Mount Tahan, Malay Peninsula (Waterstradt).

\section{Banisia lepida spec. nov.}

Forewing: shining whitish ochreous, crossed by pale olive-brown bands; the basal vertical, with straight outer edge; antemedian vertical, narrow at costa and swollen below; postmedian forked narrowly at costa, then much swollen, forked again below middle, the inner arm broad, running to two-thirds of inner margin, with a slight angle inwardly on median vein and outwardly on vein 2 , the outer arm ontcurved and much narrowed, sometimes interrupted, ending in a triangular rufous blotch, the sides of which are at anal angle and end of vein 2 ; a narrow subapical brown line from costa to end of vein 4, sometimes, but rarely, forming a fork at costa with the preceding costal blotch; the whole faintly strigulated; fringe brown.

Hindwing: suffused with pale rufous, the costal area remaining pale ochreous ; median and postmedian donble lines rising each from a point on vein 6 , sometimes confluent laterally ; a single brown subapical line.

Underside pale fulvous, with the lines and bands deeper fulvous.

Head, thorax, and abdomen shining pale ochreous; palpi and forelegs fulvons.

Expanse of wings : 33 to $44 \mathrm{~mm}$.

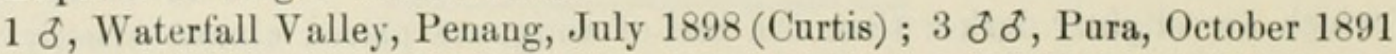

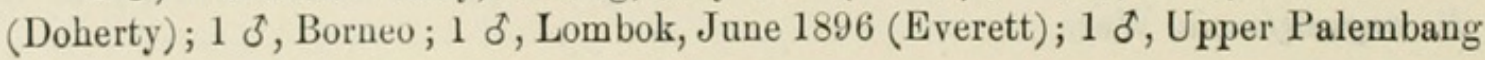


district, Sumatra (Voelcker); 1 o , Mindoro lowlands, November 1895 to January 1896 (Whitehead); and $1 \delta$ from Tanah Massa, Batoe Islauds, September 1896 (Kannegieter) type.

Paler and generally smaller than $B$. taeniata, described below, from which it may be distinguished not only by the shape of the bands on forewing, but by the subapical line on both wings. $q$ not known. As is only natural in an island species, the examples vary much in size (and slightly in markings) according to locality, the specimen from Borneo being smallest, and those from Sumatra and Mindoro the largest.

\section{Banisia ocellipennis spec. nov.}

Forewing: semi-transparent ochreous, the basal two-thirds suffused with dull red-brown except an erect oval patch reaching from cell above the origin of vein 2 to submedian vein; the edge of the brown area runs from four-fifths of inner margin to three-fourths of costa, forming three sinuses, separated by projecting teeth on veins 2 and 5 produced as brown streaks to outer margin; the brown colouring extends narrowly along costa to apex subtending a triangle before apex, from which a red line runs to the streak at end of vein 4, forming there another small triangle; from the middle of the streak along vein 4 a vertical streak falls to the end of the streak on vein 2 ; the marginal area is thus cut up into five irregular patches, reticulated so as to present the appearance of an aggregation of irregular cells; the inner margin below vein 1 also shows some pale red-centred cells; fringe (woru) brownish.

Hindwing : ochreous, cut up by reddish streaks into irregular roundish blotches of cells, and crossed at middle by an irregular brown band; veins, as in forewing, finely red.

Underside the same; the hindwing altogether paler.

Thorax and abdomen red-brown; head and shoulders ochreous mixed with brown.

Expanse of wings : $40 \mathrm{~mm}$.

$3 q f$ from Lower Burma.

Allied to ferrofusa Hmpsn. and illustrata Warr. The onter margin of both wings is strongly bulged below middle, and the apex of forewing acute.

\section{Banisia ramifera ab. conformis nov.}

In the type form of ramifera Warr. the coloration is uniform in both sexes, the bands and markings being only a little darker than the ground ; the aberration conformis mimics to a certain extent $B$. lateralis Warr., having black blotches in both branches of the outer fascia of forewing on each side of vein 3 , and in the hindwing on each side of vein 2 ; the difference in the lines will always distinguish them, these being curved and sinuous in ramifera, vertical and angular in lateralis; also the dorsum in the former is dark fuscous, without dots, in the latter pale ochreous and with two rows of dark dots.

$1 \delta$ from Kumusi River, North-East British New Guinea, low elevation, June 1907 (Meek).

\section{Banisia taeniata spec. nov.}

Forewing: greyish-ochreous with a pink tinge, paler along costal half, more rufous along inner mairgin ; varied with fine striae and crossed by concise chestnut- 
brown bands with somewhat ragged edges; two near base, the inner one obscure ; sn antemedian bent outwards in cell; a postmedian, broad and forked at costa, sharply angled outwards on vein 5, then incurved; a narrower streak, also widely forked at costa, from before apex to onter margin at vein 4 ; two short bands at anal angle, laterally confluent, becoming pointed on vein 4 ; the inner sometimes united by a dark line with the angle of postmedian band; fringe dark chestnut.

Hindwing: with traces of four bands, less defined than those on forewing, narrow at costa, diffusedly broadening ont below.

Underside paler with partial fulvous suffusion, the bands bright fulvous; those at anal angle much reduced.

Head, thorax, and abdomen like ground colour of wings.

Expanse of wings : $44 \mathrm{~mm}$.

$5 \delta$ from the Khasias (type); 1 o Sikkim 1889 (Pilcher).

\section{Banisia tetragonata Wlk. subsp. ordinaria Warr.}

These are undonbtedly local forms of one species: typical ordinaria from Australia are on the average the smallest of all the forms, except those from Amboina, which are equally small; tetragonata from Borneo, the Malay Peninsula, and India the largest. The examples from New Gninea and the Louisiade Islands are larger than the Australian ; while those from the islands of the Solomon group come next in size to tetragonata. A noticeable point of difference is that in the ab. hyphenata the black dash in the Solomon Islands examples is always below vein 2 , in all the other forms above it.

\section{Beguma radiata spec. nov.}

Forewing: fulvous brown, with broad, abbreviated, slightly glossy, pale ochreous bauds from costa, each with the centre fulvons, the darker ground colour forming long wedge-shaped bands between them; three of these pale bands, in the basal half of wing, are somewhat oblique outwards, the two beyond the middle oblique inwards, especially the ontermost, which rises from costa before apex and euds in midwing at vein 4 ; the four oihers are indistinct below submedian vein, the dark ground colour in the lower middle of wing becoming blackish-brown ; all the veins in submarginal area are marked by pale fulvous ochreous rays, that on vein 6 being least conspicuous, those on 3 and 4 forming the ends of a broader curved streak from three-fourths of inner margin; fringe fulvous.

Hindwing: with a pale antemedian band, a band from middle of costa widening downwards and forking below middle, one branch running to anal angle but bifurcating along vein 2 , the other bifurcating to outer margin along veins 3 and 4 ; vein 5 also pale-rayed; the apex with a semi-elliptical pale costal blotch; fringe fulvous.

Underside like upper, but the pale spaces emphasised.

Head, thorax, abdomen, and legs all fulvous.

Expanse of wings : $30 \mathrm{~mm}$.

$1 \delta$ from Luebo, Kassai River (P. Landbeck).

I refer this species to Beguma for the present: the type of the genus, B. constellata from India (still unique), is a $f$ with strongly lamellate antennae; the $\delta$ of the new species has bipectinate antennae, but the pectinations are short and thickened at their apex, like developed serrations; the forehead is strongly bulged; both wings with well-rounded angles and outer margins. 


\section{Belonoptera arachnidia spec. nov.}

Forewing: pale grey, thickly covered with minute irregular darker reticulations; the lines and shading red-brown; basal fourth rather darker, edged by a very irregular enrved line, followed by an equally irregular median line ; from nearly two-thirds of costa an oblique thick line forked at costa runs to middle of inner margin; space beyond shaded with red-brown, narrowly above, but reaching outer margin at vein 2 , forming roughly an A-shaped mark; a black subcostal streak in onter fourth running out into apex, from the base of which a red-brown streak forked at origin runs to onter margin at vein 4 ; all the paler intervals filled with fine cobweblike markings ; fringe dark brown with paler tips.

Hindwing: with a long white streak, narrow at middle, along the discocellular ; the space beyond it rather deeper suffused; all the intervals filled with cobweblike irregular markings; the apex and some streaks before it darker.

Underside like upper, but the ground eolour paler and the markings clearer.

Head, shoulders, and basal half of patagia reddish brown; tips of patagia, the thorax, and two basal segments of abdomen pale grey; rest of dorsum brownish red.

Expanse of wings : $82 \mathrm{~mm}$.

1 f from La Oroya, R. Inambari, S.E. Peru, 3100 ft., October 1904, wet season (Ockenden).

\section{Brixia australiae spec. nov.}

Forewing: pale greyish fawn-colour in basal half, reddish fawn in the outer; basal area traversed by two faint brownish bands, the paler intervals forming bands of the same width each with a dark line through it; a similar pale band is visible at two-thirds of inner margin, hardly reaching midwing ; a large whitish triangular costal blotch before apex, with the veins and striae across it fawn-colour; a faint pinkish mark at apex before fringe, and a black spot on margin above vein 5 ; fringe with basal half dark leaden brown, apical paler.

Hindwing: with basal area pale lilac-grey, with darker striations; rest of wing reddish fawn, showing traces of a paler dark-centred postmedian band ; fringe wholly fawn-coloured.

Underside with the dark and pale bands more clearly defined, the dark markings deeper brown, and the striae more conspicnons; black spot of forewing large, the apical mark above it white.

Head and shoulders deep chestnut; thorax and abdomen pale lilac-grey, the anal half of dorsum browner, the anal extremity fulvous.

Expanse of wings : $28 \mathrm{~mm}$.

2 $q$ from Yeppoon, October 1890 (Barnard coll.).

\section{Brixia comparalis spec. nov.}

Forewing : very much like disparalis Hmpsn. from Ceylon, but the subapical costal blotch is broadly triangular, not attenuated, marked with two small brown dots on the costal edge, which is tinged with yellow, the white apical portion with faint brownish reticulation; a slight white streak before fringe from costa to vein 6 ; basal and outer areas paler fawn-colour than the central, which is broadly olive-brown on costa, including the space between the two white marks ; narrowing off to a diffuse smoky brown oblique band at middle of inner margin ; a black spot 
before fringe above vein 5 ; a few dark dots and strigae in the basal half; fringe concolorous.

Hindwing: with the smoky brown band continued across wing to inner margin above anal angle, broader and with a darker central stripe; rest of wing pale ochreous fawn; the fringe rather deeper fawn.

Underside much dnller ; forewing with a purplish grey flush beyond middle ; striae more prominent, especially in hindwing, which shows no trace of thè dark band.

Head and shonlders deep chestnut-brown; thorax and abdomen pale greyish ochreous; base of anal segment with a brown blotch.

Expanse of wings : $26 \mathrm{~mm}$.

$2 \delta \delta$ from the Khasia Hills.

\section{Dohertya submicans spec. not.}

Differs from D. astradora Meyr. by the absence of the paler intervals between the dark bands, the whole surface of both wings being leaden fuscous.

Forewing: crossed by four dark lines, subbasal, antemedian, postmedian, and outer, and a short submarginal line to middle of onter margin; all the intervals crossed by parallel lines of dots ; at end of cell a dnll dark clond containing some brown scales, as if burnt; fringe fuscons.

Hindwing: with the outer lines only.

Underside of forewing with the markings as in astradora, but the brown ones more developed; a bed of black and metallic scales in cell, and a streak of black scales along subeostal vein beyond cell; hindwing shining whitish, crossed by rows of sharp black striae between the veins, here and there marked with brown.

Head, thorax, and abdomen fuscons.

Expanse of wings: $16 \mathrm{~mm}$.

2 ơ from Dorei, Dutch New Guinea, June 1897 (W. Doherty).

15. Draconia accipitrina spec. nov.

Forewing: whitish, the veins and reticulations pale brown, the bands dark brown; basal third suffused with brown; a broad oblique fascia from middle of inner margin and a conical blotch from anal angle brown, the two nniting above vein 5 and reaching the costa as a narrow band at two-thirds; the whitish areas, which are semihyaline, are therefore a narrow obliqne band between basal patch and central fascia reaching as far as subcostal vein, and a broader one beyond the fascia reaching vein 5 ; there are also three ronndish hyaline spots beyond the joint fasciae between veins 4 and 7 , edged outwardly by black spots which are continued towards costa ; apex whitish, traversed by a brown streak along vein 8 , which joins at right angles a brown costal spot, from which a brown line, interrupted by the veins, runs to near outer margin on vein 4 ; fringe dark brown, with pale tips and deeper brown beyond the veins.

Hindwing: with the base only narrowly brown; the donble fascia as in forewing, but its central area narrower; the apical area with more numerous hyaline spots, traversed by a curved brown streak from three-fourths of costa to a brownish cloud at middle of outer margin; submarginal line more interrupted; the apex not white.

Underside with the basal areas and the fasciae dark brown and distinct; the rest of both wings pale fawn-colour, the veins not brown, 
Head, thorax, abdomen, and legs dark brown ; dorsum with a fine black line. Expanse of wings : $78 \mathrm{~mm}$.

16 from Bogota, Colombia.

The apex of both wings is produced and the onter margin erenulate, and sinnons only, not elbowed or angled at middle.

\section{Draconia albiapicata spec. nov.}

Forewing: ferruginons ochreons, the lines and reticnlations darker ferruginons ; a dark brown costal streak running ont into apex, the extreme edge paler in onter third; some brown streaks in basal half of cell, with a ferruginons blotch at one-third; an oblique ferruginons line just beyond middle, forked at costa and inner margin, the lower fork filled up with ferrnginous; the npper fork emits a curved line towards a large oval ferrnginons blotch lying between veins 2 and 3, above a bullet-shaped blotch at anal angle; a brown line from the costal-streak at five-sixths runs down towards anal angle parallel to outer margin; the intervening spaces covered with fine interlacing lines; the outer margin deeper ferrnginons; apex whitish; fringe brown.

Hindwing: with a curved ferruginons line at one-third, followed by a small white spot at lower end of discocellular ; some irregular coalescent dark ferrnginous blotches below costa before apex, which is whitish; a round ferruginons blotch between veins 2 and 3 , above a streak from anal angle; outer margin above middle deeper ferruginons.

Underside the same, but the dark markings better defined; the apex of both wings white; the white cell-mark visible on forewing also.

Head, palpi, shoulders, and a dorsal streak along abdomen deep ferruginons ; thorax, patagia, and rest of abdomen paler varied with brighter.

Expanse of wings : $65 \mathrm{~mm}$.

$1 \delta$ from La Oroya, R. Inambari, S.E. Pern, $3100 \mathrm{ft}$., March 1905, wet season (Ockenden).

Resembling B. frondicula Gnen., bnt the outer margin in both wings excavated in upper half and crenulate in lower.

\section{Draconia dismutata spec. nov.}

Much resembling D. basipleta Warr., Proc. U. S. Nat. Mus. xxix. p. 349, from British Guiana, from which it differs as follows : the brown markings are all paler, more rusty brown ; the basal patch of forewing covers quite one-third of the wing instead of only one-fourth; the costal streak is much broader thronghout, and the second of the projections depending from it is qnite close to apex and not connected by a line with outer margin ; vein 2 is not marked with brown. In the hindwing the oblique line from two-thirds of costa to onter margin, which cnts off an equilateral triangle in basipleta, is absent, and is represented by a broad brown streak from shortly before apex, forming a $Y$ with the broad margiual line. In both wings the pale ground colour is tinged with rufous, and the reticnlations and veins of hindwing are red.

Expanse of wings : $\delta 40 \mathrm{~mm}$. ; $\$ 50 \mathrm{~mm}$.

A pair from Fonte Boa, Upper Amazons, August 1906 (Klages).

\section{Draconia stenoptila spec. nov.}

Forewing : brownish ochreous; the bands and reticulations dark brown, the costa irregularly duller brown; iuner margin beyond middle dark brown, emitting two 
irregular oblique bands, one at middle running to a subquadrate subcostal bloteh beyond cell, the second geminate from and from before anal angle, uniting above middle and joining a broad triangular subcostal blotch before apex; the rest of the wing with numerous transverse brown lines that form slight and partial reticnlations ; fringe brown.

Hindwing: with a broad blackish brown antemedian band, formed by the amalgamation and continuation of the three dark bands of forewing; a dark brown spot at base ; rest of wing with fine ramifying brown lines.

Underside paler, the bands plainer; the reticulations and costal streak of forewing quite dull.

Head, thorax, and abdomen brownish ochreous ; palpi and a band on third and fourth segments of abdomen dark brown.

Expanse of wings : $35 \mathrm{~mm}$.

1 from Caparo, Trinidad, December 1905 (Klages).

The shoulders and the costal area of forewing are glossy; outer margins of both wings crenulate. Distinguished by the long narrow forewings.

\section{Draconia timida spec. nov.}

Forewing: whitish; the veins and minute reticulations brown; the costal streak and basal third suffused with brown; a postmedian and a snbmarginal, inwardly oblique, narrow brown band, both swollen at inner margin; a narrow brown marginal shading; fringe pale, chequered with brown beyond the veins.

Hindwing: with the transverse bands all more or less laterally connected.

Underside paler, with all the markings more distinct, reddish brown.

Head, thorax, and abdomen brown with white speckling ; vertex paler.

Expanse of wings : $22 \mathrm{~mm}$.

1 f from Fonte Boa, Upper Amåzons, May 1906 (Klages).

20. Dysodia confusata spec. nov., and ab. olivescens nov.

Of the same size and shape as speculifera Sepp, but with all the dark markings amplified and the ground colour, whether reddish or tawny, restricted and suffused with a deeper tint; the basal and antemedian curved lines of the forewiug are swollen into dark bands; the onter band is broad throughout, its inner margin projecting at middle so as sometimes to tonch the antemedian band; in the hindwing the paler areas are still more reduced by the widening of the bands; the hyaline spot is much smaller and figure-of-8-shaped.

Head, thorax, and abdomen all similarly darkened by the blackish suffusiou.

Expanse of wings : $\delta 30-32 \mathrm{~mm}$.

Three of of from Zamora, Ecuador, $3000-4000$ feet (O. T. Baron).

Of these, two have the ground colour deep coppery red, the third has it olive tawny ; a fourth specimen, from the same locality, an extreme development of the third, must be separated as åb. olixescens, the whole of both wings being suffused with dark olive-fuscons, so that the underlying paler areas are obscured, and the hỵaline bloteh is swollen so as to appear like a large cottage-loaf: head, thorax, and abdomen all olive-fuscous.

\section{Dysodia constellata spec. nov.}

Forewing: pale yellow ochreous, the basal two-thirds suffused with pale olive, obscuring the antemedian band: an oblique dark olive-fuscous band from beyond 
middle of inner margin, swelling ont towards costa and extending to apex, before which it emits a dark streak to middle of onter margin, followed above vein : by a small yellow spot; the marginal area between the fascia and this streak is pale yellow between veins 2 and 5 , tinged with olive above and below them, the veins themselves brown with a few neat trausverse streaks, thickened into a slight vertical blotch from anal angle; fringe with basal half olive-fuscous, onter half paler beyond the two folds; costa with short pale streaks.

Hindwing: with the space below cell-fold and vein 5 yellow, with the veins lrown and the transverse markings well developed; costal area suffused with olive ; a broad irregular dark central fascia, forked and olive-tinged at anal angle; a small oval hyaline spot in npper end of cell ; fringe olive, tipped with yellow below middle.

Underside similar, but the coloration duller.

Head and thorax dall yellow with an olive tinge; dorsum browner, except the anal segment; abdomen beneath pale ochreous like the legs; forelegs and palpi brown.

Expanse of wings : $28 \mathrm{~mm}$.

1 \& from Zomba, Upper Shiré River, 3,000 feet, December 1905 (Dr. P. Rendall).

\section{Dysodia crassa Wlk., ab. flavidula nov.}

Like crassa, but with the ground colour dull yellowish instead of red.

In both forms the $q$ is rather larger than the $\delta$ and much darker, the pale ground being almost hidden by fuscous suffusion, which also darkens the head and thorax and to a less degree the abdomen. On the underside the costa and onter band of forewing are olive-green, more conspicnonsly in the type form than in Alavidula.

Three $\delta \delta$ from Congella, Durban (G. F. Leigh), received with a pair of typical crassa.

A preserved larva (of the yellow form) is yellowish grey marbled with black, and with apparently irregular blackish subdorsal blotches; the tubercles beset with short curved spines ; head black ; front of second segment with a black bar.

\section{Dysodia derufata spec. nov.}

Differs from speculifera Sepp in being ochreous, sometimes with a fulvous tinge, without any red suffusion except on abdomen; the reticulations are more minute and regular, taking the form of short transverse streaks between the veius, which are themselves also fuscous; this is especially noticeable in the hindwings, where the dark submarginal curve is quite absent; the hyaline cell-spot of these wings is reduced to two small subcontiguous round spots.

2 \& \& from Castro, Parana, Brazil.

\section{Dysodia flagrata.}

Varnia flagrata Wlk. xxxiii. p. 827 (1865).

This species is distinct from speculifera Sepp; the costa of forewing is dark brown from base to onter baud; and this band, instead of being funnel-shaped as in Sepp's species, forms a subquadrate blotch on costa reaching to vein 5 , from the inner angle of which a dark oblique line runs to beyond middle of inner margin, while from its outer angle an irregularly-bent streak runs to anal angle; the cell-spot of hindwing consists of two small hyaline white dots, limited externally by a black central line which is thickened into a blotch above the median vein, 
The underside is pale brown with the markings olive-brown; the inner marginal half of hindwing broadly yellowish. In the $f$ the reddish fulvons ground colonr is almost hidden by dark fuscous suffusion in both wings.

The species varies in point of size: $2 q q$ from Ecuador measure $32 \mathrm{~mm}$. in expanse, whereas of fonr examples from Venezuela one, a $\delta$, is only $28 \mathrm{~mm}$. and the three $q$ \& $26 \mathrm{~mm}$.

\section{Dysodia innubila spec. nov.}

Differs from $D$. speculifera Sepp in being deeper, more uniformly copper red; the reticulations therefore are less prominent; the lower half of the postmedian funnel-shaped band of forewing is narrower, and the apical area beyond the obliqne submarginal streak broader and darker; the red area between these two runs up to the costal margin, whereas in speculifera the costo-apical area is clonded as far as vein 6 . In the hindwing the large hyaline blotch is not only rednced in size, bnt separated into two small but unequal spots.

Expause of wings : $\delta 28-30 \mathrm{~mm}$. ; \& $30 \mathrm{~mm}$.

$1 \delta$ (type), Charaplaya, Bolivia, $1300 \mathrm{ft} .$, July 1901 (Simons); 1 ठे, Chirimayo, Peru, 1000 ft., July 1901 (Ockenden) ; 1 \&, Oconeque, Carabaya, Pern, 7000 ft., July 1904 (Ockenden).

\section{Dysodia spissicornis spec. nov.}

Forewing: dull reddish fulvous, more or less suffused with olive-fuscous, most densely along costa and inner margin; the reticulations and bands fuscous; basal and antemedian bands narrow, the postmedian broader, projecting outwards above middle, and darkened on submedian interval ; costa with four pale marks, one before, the others beyond the middle; fringe brownish, ochreous in the two crenulations above anal angle, and slightly beyond cell.

Hindwing: with numerons darker reticulations, but withont distinct lines; inner margin more fulvous, less suffused with olive; cell-spot double, consisting of a small white dot at upper end of discocellular and a slender curved mark at its lower end.

Underside paler, brown with a pink tinge, the markings olive-fuscous; these in the forewing are a narrow antemedian and broad postmedian band, the latter interrupted in the middle, and an apical patch; inner margin of hindwing yellowish.

Head, thorax, abdomen beneath, and legs olive-brown; metathorax and tips of patagia mixed with fulvous; dorsum with a pinky grey sheen, aud laterally on anal segments reddish; third segment whitish with a black belt; antennae fulvons brown, with strong fascicles of cilia, which will at once distingnish the species in the $\delta$.

Expanse of wings : $32 \mathrm{~mm}$.

2 ठั ठठ from Rio Janeiro.

\section{Dysodia thyridina Feld.}

This also is an entirely different species from speculifera Sepp. The gronnd colonr is ochreous suffused with brownish fulvous, not orange-red; the dark costal suffusion in both wings ampler; the reticulation more minute, and assuming the form of round pale spots between the veins; the cell-mark of the hindwing is shaped as in oculatana Clem., the two spots being contignous in the $q$, and 
separated in the $\delta$ (in one $\delta$ rednced to two small dots); it is preceded, not followed, by a dark band.

The underside is pale grey frosted with bluish white, with the darker markings and reticulations olive-fuscous.

Head and thorax dark fuscons; metathorax and patagia redder; the dorsum fuscous varied with reddish, with a dark belt on third segment.

Felder's type, a $f$, is labelled Guyana ; $3 \delta \delta$ in the Tring Musenm come respectively from Zamora, Ecuador, Pozuzo, Pern, and R. Dagna, Colombia.

\section{Dysodia subsignata spec. nov.}

Differs from crassa. Wlk., with which it agrees in size and markings, in having a large heart-shaped hyaline blotch on the hindwing; the forewing beneath has the dark outer band terminating in a triangular black-scaled patch reaching from vein 5 to the submedian fold; on the upperside this band is not so wide at costa as in crassa, its onter edge more irregular.

$1 \delta, 1+$, from Congella, Durban (G. F. Leigh), the $\delta$ agreeing in colour with the aberr. Aavidula of crassa Wlk., and the $q$ with crassa itself.

\section{Herdonia miranda spec. nov.}

Forewing: pale ochreous, washed in parts with pale brown; costa with base and two double transverse streaks close to it deep green with brown streaks in between; costal edge dotted with dark green; the green streaks continned below cell to inner margin and followed in submedian interspace by transverse green and brown striae; from submedian vein at middle of wing an oblique green band widening outwards runs to below vein 6 near outer margin, where it 1s narrowed off and blunt, edged on each side by a white line, the white edges connected along submedian fold; from before the anal angle a brownish streak with dark edges runs obliquely to onter margin at vein 6 , connecting with a brown apical blotch containing some ronnd white spots; fringe short, pale brownish ochreons.

Hindwing: similar, the green blotch shorter, and becoming brown above median vein.

Underside the same, with all the markings more defined.

Head and palpi cream-colour ; patagia very glossy, brownish ochreous ; abdomen greyish ochreous; basal segments crossed by tufts of brown and green scales; legs and abdomen beneath ochreous, the femora and tarsi brown.

Expanse of wings : $\delta 35 \mathrm{~mm}$. ; $+5 \% \mathrm{~mm}$.

1 б, 1 \&, from Fonte Boa, Upper Amazons, July 1906 (Klages).

\section{Hypolamprus albipunctula spec. nov.}

Forewing: dnll brownish grey; costal area darker grey, but the costal edge pale ochreous dotted with blackish; numerons dark grey striations forming $\mathrm{X}$ shaped marks in outer half; a broad oblique dark grey band bejond middle running parallel to onter margin, marked by black dashes below vein 2 and on each side of vein 6 , followed by a paler fascia of roundish white spots separated by darker marks, the two pale spots above vein 6 being chalk-white, sometimes followed externally by a third beneath the whitish apical spot with a black dot in it; fringe glossy grey.

Hindwing: with the veins and margins brownish grey, the rest of the wing filled with small round white spots between the veins separated by transverse 
darker striae; a square black spot at end of cell and an elongate one half-way between it and outer margin.

Underside paler; both wings with numerons dark $\mathrm{X}$-shaped markings: forewing with a pinky whitish apical blotch containing a black spot; streaks of black and yellow metallic scales along upper margin of cell and at its base.

Head and thorax dull grey; the abdomen paler.

Expanse of wings : $24 \mathrm{~mm}$.

1 f from Lower Burma (type); another from Mao, N. Manipur (W. Doherty).

Nearest to $H$. inductalis $W l_{k}$. = peratopis Hmpsn., but duller in appearance distinguished by the whitish hindwings.

\section{1: Hypolamprus inductalis.}

Pyralis inductalis Wlk., xxxiv. p. 1525 (1865).

Hypolamprus peratopis Hmpsn., P.Z.S. 1897, p. 615.

Hypolamprus subnictitans Warr., Nov. Zool, iv. p. 380 (1897).

Through the kindness of Professor Poulton I have lately been able to examine some of Walker's types of Thyrididae in the Oxford Mnseum. The type of $P$. inductalis Wlk. from Ceram, notwithstanding its condition, I have identified with Hypolamprus peratopis Hmpsn. from Borneo, Amboina, and Fergusson Island, and my own subnictitans from Penang.

\section{Hypolamprus polycyma spec. nov.}

Forewing: whitish along costal edge and broadly along inner margin; the rest of the wing and the veius olive-ochreous; the whole surface between the veins covered with grey-brown dappled marks, which in the darker suffusion are more or less hidden; costal edge with four black spots beyond the middle; a white line at base of fringe from anal angle to vein 4, to which point another white line converges from five-sixths of inner margin; fringe olive-ochreous, with a fine black dividing line, and mottled with black in onter half, interrupted by a pale patch between veins 4 and 5 ; the apex also pale.

Hindwing: with the olive-grey ripplings all parallel to the outer margin; an indefinite pale band before middle with the black cell-spot on its onter edge; a narrow pale line from four-fifths of inner margin to costa before apex, where it is followed by a brown spot, and a similar white line before the fringe, which is waved like the margin, with a waved black dividing line, the inner half ochreous, the onter whitish.

Underside the same, but clearer.

Head, thorax, and abdomen ochreous grey, the thorax and patagia darker.

Expanse of wings : $40 \mathrm{~mm}$.

1 \& from Mt. Marapok, Dent Province, British North Borneo.

Forewing with straight costa and acute apex; outer margin very strongly bulged in middle, concave above and strongly oblique below; hindwing with outer margin nearly straight, with only a slight indentation below the produced apex.

33. Hypolamprus subrosealis Leech, ab. rubicunda nov.

The form of this species occurring in the Khasia Hills, for which this name is proposed, is both larger and brighter red than typical examples. Of 13 \& $\delta$ and 5 \& $\&$ from Ceylon, Penang, Borneo, Sumatra, Sumba, aud Tambora the 
largest $\delta$ expands only $22 \mathrm{~mm}$., the largest $q 25 \mathrm{~mm}$. : while of $7 \delta \delta$ and $3 q q$ from the Khasias the $\delta \delta$ vary from 22 to $28 \mathrm{~mm}$, and the $q f$ from 30 to $32 \mathrm{~mm}$. The coloration of the $q q$ and of most of the $\delta \delta$ is bright brick-red, especially in the hindwings, the costal area of forewings paling off to brownish ochreous. The dorsum, like the hindwings, is bright red.

\section{Hypolamprus semiusta spec. nov.}

Forewing: pale brownish ochreous, washed with fulvous along inner margiu and iu basal area; fulvous antemedian and median fasciae with somewhat darker edges, and becoming more or less obsolete towards costa, where the brown patches indicating fasciae are separated by pale intervals with a brown line at middle; outer half of wing with a few indeterminate brown striae; three patches of black-brown scales running out into the ochreous fringe in upper half of outer margin, the lowest joined by a short fulvons band from costa.

Hindwing: wholly suffused with fulvous, and with dark striae, which form indistinct antemedian and median curved bands.

Underside paler, with the dark markings plainer, especially the lower parts of the antemedian and median bands of forewing, which are black-brown.

Head, thorax, and abdomen all fulvous; the fillet and antennae paler.

Expanse of wings : $\delta 18 \mathrm{~mm}$. ; $+18-24 \mathrm{~mm}$.

1 d, 2 $q$, from Kumusi River, N.E. British New Guinea, August 1907, low elevation (A. S. Meek).

Allied to H. stylophora Swinh. from India.

\section{Hypolamprus simplex spec. nov.}

Forewing: grey with a pink tinge ; the cell and central area pinkish ochreous ; costal area paler grey ; a few dark dots and striae across basal half, not forming lines ; from beyond middle of inner margin an oblique dark grey band of three fine lines ruus parallel to outer margin to vein 5 , where it becomes obsolete, but appears to curve round to costa ; a black apical dot; fringe glossy.

Hindwing: piakish fulvous, with the grey band of forewing continued across the middle, narrowing to inner margin, followed by a pale band with darker central line, and by three submarginal grey lines.

Underside with all the dark markings clearer; upper margin of cell with streaks of black and yellow scales which also fill the base; apical black spot on a pinky blotch.

Head, thorax, and abdomen dull grey, the last pink-tinged.

Expanse of wings : $18 \mathrm{~mm}$.

2 ơ ठै from Maymyo, Shan States, June-August 1902 (Hauxwell).

Onter margins of both wings evenly curved.

\section{Hypolamprus squalida spec. nov.}

Forewing: pale brownish ochreous with an olive tinge; the basal area dull brown; five darker irregular bands, marked by brownish strigulae; a basal and antemedian straight or slightly curved; a postmedian from three-fourths of costa to two-thirds of inner margin, its lower end vertical, and apparently throwing off a branch from median to costa at middle; a narrow line of dark striae beyond it, and a submarginal double row of striae, the space between them filled up with brown from costa to middle. 
Hindwing: with the bands interrupted; one postmedian well marked on inner margin; the whole marginal area olive brownish; at the end of cell a square white spot followed by a subquadrate dark brown one with blackish edges, then a more rounded white one followed by a second brown one; at the anal angle a brownish yellow patch.

Underside the same, the markings somewhat plainer.

Head, thorax, and abdomen brownish ochreous.

Expanse of wings : $36 \mathrm{~mm}$.

1 o from Lifu, Loyalty Islands.

The only example is considerably worn, but is evidently a distinct species.

\section{3\%. Hypolamprus stabilis spec. nov.}

Forewing: reddish-brown, the same colour as $H$. angulalis Moore, bnt browner along costa and at base; the costa with oblique brownish streaks, not dotted ochreous and black; the transverse darker striae mainly vertical ; indistinct traces of an antemedian and postmedian band; in the clearer subapical space are four elongate black dots in a vertical line, instead of the single round black dot on a white patch as in angulalis; fringe glossy, dark in basal, yellowish in apical half.

Hindwing: with series of dark transverse striae.

Underside pinker, all the markings much clearer and tinged with brown; fringe pink, with the basal half plumbeous ; streaks of velvety black and yellow scales at base of cell and along subcostal vein and vein 8 to apex.

Head, thorax, and abdomen like wings.

Expanse of wings : $30 \mathrm{~mm}$.

$1 \uparrow$ from north side of Choisenl Island, December 1903 (type), and $1 q$ from Florida Island, January 1901 (A. S. Meek).

The species is much stonter than angulalis ; the wings broader, and with only a very slight projection in middle of outer margins.

\section{Hypolamprus vinosata spec. nov.}

Forewing: yellowish ochreous, with vinous brown bands and striae ; the basal area and inner margin diffusely vinous; at two-thirds an oblique brown fascia, broader towards inner margin, joined at vein 6 by an oblique quadrate patch at middle of costa, the two so forming a $\mathrm{Y}$-shaped mark; an oblique streak from a costal spot before apex to middle of outer margin; the pale spaces with fine brown-red strigulations; fringe ochreous in apical half, brown in lower, with patches of black scales at apex and beyond vein 4 .

Hindwing: wholly suffused with deep vinous, with traces of transverse striae and a dark postmedian band; fringe vinous with two patches of black scales at middle.

Underside like upper, bat paler.

Head, thorax, and abdomen brown ; legs brown with pale joints.

Expanse of wings : $17 \mathrm{~mm}$.

$1 \delta$ from Oinainisa, Dutch Timor, November-December 1891 (Doherty).

Closely allied to $H$. stylophorus Swinh.

\section{Iza curvistriga spec. nov.}

Forewing: greyish fulvous, with the reticulating lines dark brown; two at the middle of costa, with brown between them, form a subquadrate patch, from 
the onter lower end of which a curved brown line runs up to apex with a black dash upon it; the cell-fold and space beyond between veins 5 and 6 are compressed, forming a kind of projecting pleat on underside and a corresponding channel above; a dark line from costa to onter margin cuts off an apical triangle; fringe fulvous.

Hindwing: fulvous with numerous brown reticulating lines; the fold along cell present, but less prominent.

Underside rather paler, with the reticulations reproduced; hindwing with abdominal margin ochreous.

Head, thorax, and dorsum deep fulvous; venter and legs paler.

Expanse of wings : $26 \mathrm{~mm}$.

2 $q$ from Aroewarwa Creek, Maroewym Valley, Surinam, June 1905 (Klages).

\section{Iza rufidorsata spec. nov.}

Forewing: chocolate-brown; the costa reddish; traversed by vertical pale lines; basal and antemedian parallel, slightly oblique inwards; a postmedian slightly bent running into anal angle; a submarginal running from costa to onter margin below middle; between these are more slender and obscure pale lines and slight reticulations; fringe brown.

Hindwing: with antemedian and postmedian lines and traces of finer ones.

Underside like upper : the costa of forewing throughout and of hindwing near base dull yellow.

Face dark brown; vertex, thorax, and dorsum bright orange-red; abdomen beneath and at sides brown.

Expanse of wings : $22 \mathrm{~mm}$.

1 ठ from Aroewarwa Creek, Maroewym Valley, Surinam, May 1905 (Klages).

\section{Iza sectilinea spec. nov.}

Forewing: straw-colour, with the veins and reticnlations finely brown; costa with small brown triangles and an oblong mark at three-fourths; a triangular brown space at apex reaching to middle, darker-edged internally, joined between veins 5 and 6 by a straight brown streak from middle of costa ; some slight brown suffusion between the reticulating lines at anal angle and beyond middle of inner margin ; fringe brown with deeper mottlings.

Hindwing: the same, but without markings except a slight brown median band containing a round black discal spot ; fringe brown.

Underside like upper.

Head and shoulders brown; thorax, patagia, and abdomen ochreous, the last with brown riugs; basal segment with a pair of black spots, second segment with one in the middle, the three forming the angles of a triangle.

Expanse of wings : $24 \mathrm{~mm}$.

2 \& from Fonte Boa, Upper Amazons, May 1906 (Klages).

Wings narrow and elongate; costa of forewing depressed at apex; outer margin sinuous.

Allied to I. gracilis Moeschler.

\section{Iza spurcatula spec. nov}

Forewing: fawn-colour, with small blackish reticulations ; a double series of these just before and beyond middle forms two interrupted bands; costa with small 
quadrate black spots, with brown dots in the intervals; some black reticulations at and below apex along onter margin ; fringe fawn colour.

Hindwing: with a blackish band at base, and a double row of dark spots across middle; some black marks at apex.

Underside the same.

Head, thorax, and abdomen fawn colour, the last spotted with black.

Expanse of wings : $19 \mathrm{~mm}$.

$1 \delta$ from Sapucay, Paraguay, September 1904 (W. Foster).

Somewhat resembling I. thiastoralis Wlk., but the ground colour is different, and the underside of forewing shows no metallic scaling.

\section{Letchena extravagans spec. nov.}

Forewing: grey-brown, with numerons short dark transverse streaks; costa paler, reddish brown; in the middle of the wing between subcostal and submedian veins a ferrnginous orange patch, containing several whitish hyaline spots between the veins, the most prominent being those at the base of the intervals between the median nervnles and one at the outside of the patch between 2 and 3 ; some smaller ones on each side of the submedian fold.

Hindwing: nniform grey-brown.

Underside similar, but the hindwing with a reddish shade across wing to anal angle, which is slightly visible on the upper side.

Head, thorax, and abdomen all grey-brown.

Expanse of wings : $34 \mathrm{~mm}$.

1 from Fonte Boa, Upper Amazons, June 1906 (Klages).

Allied to L. myrsusalis WIk.

\section{Letchenodes gen. nov.}

Differs from Letchena Wlk. in having veins 8, 9 of forewings stalked, as in Hypolamprus.

Type: Letchenodes ninniusalis Wlk. (Pyralis).

\section{Macrogonia lucida spec. nov.}

Forewing: pale ochreous, reticulated with orange-red; costal streak brownish orange; a subquadrate dark brown blotch beyond cell between subcostal veiu and vein 5, darkest below, emitting a short line to join an irregular oblique brown line from vein 7 to beyond middle of inner margin, which in its turn joins an outwardly oblique brown line from subcostal at five-sixths to outer margin; rest of wing occupied by a network of ramifying orange-red streaks; fringe uniformly and thickly deep brown.

Hindwing: with costa pale, unmarked; a dark brown antemedian line from vein 6 to inner margin, continuing that of forewing; the veins thickly orangered and some of the transverse markings tinged with brown; fringe deep brown.

Underside ochreous without the orange-red tinge; the reticulations brown; an elongate brown blotch from vein 7 to 5 beyond cell; fringe deep brown with the tips darker.

Head, thorax, and abdomen ochreons tinged and speckled with orange-red; face and palpi brown; legs ochreous and red, the foretibiae dark brown.

Expanse of wings : $\delta 28 \mathrm{~mm}$; $\uparrow 30 \mathrm{~mm}$.

4 ठั ठ์, 1 \& from Fonte Boa, Upper Amazons, June 1906 (Klages). 


\section{Microbelia fasciata spec. nov.}

Like $M$. intimalis Moore but much larger, the colouring more ochreous. The hindwings contain a dark, often blackish, median fascia from inner margin to vein 6 , including the dark cell-mark, which is continued, but less conspicuously, and only ochraceons-tinged, to the dark cell-mark of forewing; at the anal angle of hindwing is seen the blackish commencement of an onter fascia; the triangular patch before middle of outer margin of forewing is connected above by a band with two small subapical costal spots, and is often itself clouded with grey. On the nuderside, which as in M. uniformis Warr. is much brighter, the two large costal triangular marks of forewing and the blotch before onter margin are deep brown-black, the other marks being merely browa; in uniformis all alike are brown.

Head, thorax, and abdomen ochraceous like wings ; the face below and fillet whitish.

Expanse of wings : $\delta 19 \mathrm{~mm}$; $\uparrow 22-24 \mathrm{~mm}$.

$5 \delta \delta, 1$ \&, Milne Bay, British New Guinea, December 1898 (type); 1 б, Upper Aroa River, April 1898; 1 \&, Fergusson Island, December 1895; 1 \&, Kiriwini, April 1895 ; 1 \&, St. Aignan, November 1897; 1 \&, Goodenongh Island, December 1896 ; 1 $\delta$, Woodlark Island, March 1896; 3 $q$, Guizo Island,

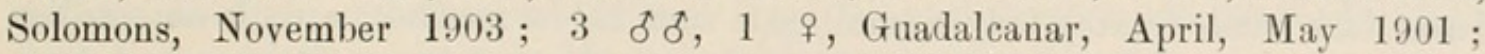
1 \&, Rendova, February 1904; 1 q, Kulambangra, March 1901 ; 4 q $q$, Choiseul Island, north side, December 1903; all taken by A. S. Meek.

\section{Microbelia privata spec nov.}

The same size as $M$. intimalis Moore, $16 \mathrm{~mm}$., but without any of the dark markings of that species, except the blackish cell-marks, the costal edging of the fasciae of the forewing, and the fringe in middle of outer margin of forewing. $3 \delta \delta, 5 q q$ from Amboina, February 1892, and $1 \delta$ from Banda taken in August of the same year (W. Doherty).

\section{Microbelia uniformis spec. nov.}

Forewing: greyish ochreous, the markings, which are broken up, hardly darker than the ground colour, with faintly paler edging; on the costa two grey triangles, a small oue just before middle and a larger one at three-fourths; a triangular mark before middle of outer margin, its onter edge black at margin, and running out into the fringe; a small round black cell-spot at lower end of discocellular; fringe concolorons.

Hindwing: with the median and outer fasciae darkened by grey scales at the inner margin only; a small black cell-spot.

Underside much gayer; the ground colour pale shining ochreous, with all the fasciae chestnut-brown finely edged with black; cell-spots lustrons, sinuous, surrounded by black scaling.

Head, thorax, and abdomen like wings.

Expanse of wings : $\delta 18 \mathrm{~mm} .$, $~ \& 22 \mathrm{~mm}$.

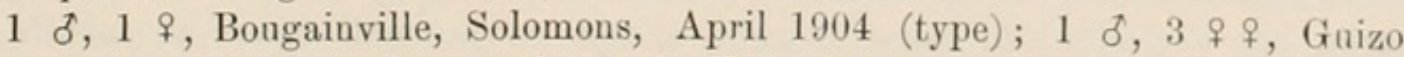
Island, Solomons, November 1903; 1 \&, Kulambangra, Solomons, March 1901; 1 o, 1 \&, Woodlark Island, April 1897 (A. S. Meek). 
4९. Obelura gen. nov.

Distinguished by the extraordinary length of the abdomen of both sexes, especially of the anal segment of the $\delta$, which is armed with two lateral brushes below; also by the strongly crenulate outer margins of both wings; and the three deep excisions in that of the hindwing between anal angle and middle.

Type : Obelura dohertyi Warr. (Banisia).

\section{Pharambara acutalis.}

Pyralis acutalis Wlk, xxxiv. p. 1523 (1865).

Microsca nitens Butler, Anu. Mag. N. H. 1887. ii. p. 116.

The type of acutalis, from Mysol, like that of inductalis mentioned above, is a considerably worn and faded specimen, but is evidently, on comparison, identical with Butler's nitens from Alu. The species is of wide distribution, occurriug, besides the Malayan islands, commonly in the Solomons, New Guinea, and North Australia.

\section{Pharambara cellulata spec. nov.}

Forewing: hyaline ochreous, the bands and strigulations dull red-brown; the inner margin, the base, and a costal streak are also suffused with brown, two basal dark bands leaving ouly a small pale spot below median; a dark antemedian band with a pale one on each side, the outer one swollen and traversed by a reddish line ; postmedian band swollen below costa and in submedian interval, almost interrupted between, forming a square spot at end of cell; a broken brown subapical streak from subcostal area to outer margin at vein 4 , and an erect streak from anal angle ending in a fork at 4 ; the pale outer portion of wing divided off by the red veins and transverse striae into aggregations of rounded cells, a line of which also appears alternated with brown along the costa; fringe (worn) red-brown.

Hindwing: with a broadly forked brown median and a narrow exenrved postmedian band, beyond which the wing is rufous-tinged, darker along outer margin; the cellular spaces touching the median band are all whitish hyaline.

Underside buff, with all the dark markings dull brown; forewing with a streak of black and yellowish hairs along npper margin of cell and beyond it, and an oblique sinuons streak of the same across cell; hindwing with the veins and discocellular clothed with shining pale scales; the costa striated with dark brown.

Head and thorax brown, the patagia ochreous and glossy ; abdomen wanting.

Expanse of wings : $33 \mathrm{~mm}$.

$1 \delta$ from West Java, 1892.

Allied to Ph. semiperforata Warr., from India.

\section{Pharambara fractifascia spec. nov.}

Like P. squamigera Pag. from Natal, but distinguished in several points :Both wings are narrower, the forewing with less prominent apex; the olive brownish suffusion of the basal two-thirds of forewing not restricted to costal area, but extending to inner margin, except on a small space at middle; no postmedian dark brown fascia, the dentate edge of the brown area ending in a subquadrate blotch on submedian interspace at two-thirds; the curved sub- 
marginal bar from costa thicker and darker; in the hindwing the brown reticnlating striae are darker and more numerous, and the central band is more broken up : in both wings the fringe is distinctly dark brown instead of ochreous.

Expanse of wings : $26 \mathrm{~mm}$.

$1 \delta$ from Ogruga, River Niger.

A much neater insect, and decidedly smaller than squamiqera; for though Dr. Pagenstecher gives $20 \mathrm{~mm}$, and $25 \mathrm{~mm}$. respectively for his $\delta$ and $q$, the six specimens in Tring Museum, all $\delta$, from Natal range from $26 \mathrm{~mm}$. to $30 \mathrm{~mm}$.

\section{Pharambara fulvipicta spec. nov.}

Forewing: cream-white, glistening; a diffuse fulvous tinge in basal half, strongest below middle; the inner margin with a plumbeous gloss; the apex fulvous; traces of three fulvous bands on inner margin, their edges marked with black spots on veins, the antemedian obscure, the postmedian oblique, the third at anal angle; in the fulvous apex close to onter margin are two small deadwhite spots edged with black, above and below vein 7, and one minute one below vein 6 ; the pale spaces are dotted, not striated, with darker; fringe pale fulvous.

Hindwing: with base plumbeous, limited by a straight deep brown antemedian band; a submarginal fulvous band at anal angle; the apex fulvous; three or four black spots along the interval between veins 5 and 6 .

Underside glossy whitish; the bands deep fulvous and strongly marked, especially the centre one of forewing; the apical white dots of forewing larger, attached to the end of a lustrous streak running below vein 8 ; some black and yellow hair scales at base and along upper margin of cell.

Head, thorax, and abdomen plumbeous grey, the face and shoulders mixed with fulvous.

Expanse of wings : $26 \mathrm{~mm}$.

$2 \delta \delta$ from the Khasias, taken in June by a native collector.

53. Pharambara moorei nom. nov.

Pharambara reticulata Moore, Lep. Coll. Atk. p. 212 (1887).

I propose this name for Moore's reticulata, as Butler had already published a Pharambara reticulata in Trans. Ent. Soc. 1886, p. 420, for an Australian insect to which Meyrick, unnecessarily, attached his MS. name crypsiria.

54. Pharambara obliquifascia spec. nov.

Like $P$. fractifascia allied to squamigera Pag., but equally distinct. The whole of the basal area within the fascia is olive-brown; the brown fascia, which in squamigera is postmedian, rising at nearly two-thirds of inner margin and slightly diverging from onter margin, here starts from the middle and runs obliquely parallel to or even converging to outer margin and is continued backwards by an equally distinct and well-margined brown fascia across the hindwing; at the anal angle, instead of the slightly thickened double stria, is a curved band of brown striae reaching vein 4 , which is likewise represented on hindwing as an interrupted sinuous reticulated band; fringes darker brown with pale apices.

Expanse of wings : $30 \mathrm{~mm}$.

$1 \delta$ from Pungo Andongo, Angola, April 1875 (A. von Homeyer).

The strong oblique fascia across both wings will at once distinguish the species. 


\section{$(344)$}

\section{Pharambara plumbea spec. nov.}

Forewing: glossy lilac-grey with a coppery tinge, crossed by vertical coppery bands; the basal and antemedian simply curved; the postmedian strongly elbowed outwards above middle; these bands are edged with darker lines; a dark submarginal line is forked at each end and preceded by coppery patches; the whole wing is varied with transverse darker strigae ; costa at base dark plumbeons ; fringe glossy, coneolorous.

Hindwing: with three coppery bands on a grey ground, basal, median, and submarginal, roundly elbowed above middle and running parallel to each other.

Underside the same, but the copper-red tints deeper and brighter; a streak of black and yellow scales along upper edge of cell and beyond.

Head, thorax, and abdomen all glossy ; the head, shoulders, and base of patagia dark plumbeous ; the abdomen mixed with red.

Expanse of wings : $30 \mathrm{~mm}$.

1 \& from Darjiling (Dr. Lidderdale).

Distinguished from Phar. curvilinea Warr. by the uniform coloration, whereas in curvilinea the costal half of forewing is much paler than the inner; also resembling Phar. reticulata Moore, but much smaller and with more regular lines and bands.

\section{Pharambara ruinosa spec. nov.}

Wings longer and narrower than in P. vittula Guen. (=exusta Butl.); the ground colour paler.

Forewing: the basal two-thirds browner; basal and antemedian obscure brown bands, the latter sometimes forked below median ; median band outwardly oblique from costa and forming a snbquadrate brown blotch at and below end of cell, very narrow, almost interrupted between veins 3 and 2, thence reaching inner margin as an oblong vertical blotch; beyond it a subcostal quadrate brown blotch, from the lower onter corner of which a curved line of brown striae runs to anal angle; a brown oblique band, bent at middle, from subcostal before apex to middle of outer margin, running out into the pale brown fringe; the whole wing with pale brown reticulations.

Hindwing: with brown antemedian and median fasciae, the latter broad and connected at middle with the former; a thick brown marginal line.

Underside like upper, with the markings plainer, the median fascia of forewing black-brown; streaks of black and yellowish scales along upper edge of cell ; costa with brownish triangles separated by pale ochreous intervals; a chestnut-brown subcostal streak in outer half of wing.

Head, thorax, and abdomen brownish ochreous.

Expanse of wings : $\delta 30 \mathrm{~mm}$.; $+35 \mathrm{~mm}$.

1 o, 1 \&, Sikkim, $188 \%$ (Pilcher).

Distinguished from vittula Guen. (=exusta Butl.) by the irregular interrupted median fascia and the square subcostal blotch following it, as well as by the longer, narrower wings ; vittula Guen. was described from N. China, and exusta Butler from Japan, and I have not seen this form from India.

57. Pharambara sublucens spec. nov.

Forewing: pale stone-grey, with faint brownish strigulations; costal edge with eight deep chestnut-red spots, alternated with pairs of pearl-grey streaks; the first 
three red spots cross the wing as faint lines and form a basal patch which is distinct only towards costa ; the second three similarly form a truncated triangular bloteh beyond cell, its edges produced across wing and ending in a slight blotch beyond middle of inner margin ; from the eighth blotch a curved brown line runs to outer margin at end of vein 4, throwing off at vein 5 another curved streak to outer margin above anal angle; two black submarginal dots, one on each side of vein 7 ; fringe chestnut-brown.

Hindwing: with faint rufous strigulations ; fringe and outer margin just before it rufous, a slight dark mark forming the commencement of a band on inner margin above anal angle, and a faint subapical curved streak.

Underside satiny whitish, especially the two submarginal patches beyond the curved lines, of which the apical one of forewings is silvery white with the two black dots on it ; all the dark markings and the strignlæ of both wings deep bright chestnut ; a line of brilliant metallic scales along upper margin of cell, and another, less conspicnons, along the lower; the retinaculum glossy.

Head, palpi, and forelegs chestnut-brown; shoulders, patagia, thorax, and anal half of dorsum mouse-grey ; basal segments paler ; venter glossy white.

Expanse of wings : $27 \mathrm{~mm}$.

$2 \delta \delta, 1 \&$ from the Angabunga River, British New Guinea, $6000 \mathrm{ft}$., November 1904 to February 1905 (Meek), type ; $2 q q$ from Biagi, Mambaré R. (Meek), 1 \& from Little Kei Island (Kühn). Allied to Phar. bracteata Hmpsn. (=rufareta Hmpsn.).

\section{Plagiosella ochracea spec. nov.}

Forewing: ochraceous, rather brighter than $B$. aurata Butler, which it much resembles superficially; costa and lines brown; two curved lines near base; a median line broadly forked at costa and inner margin, the forks often filled in with brown ; an onter line curved externally, also forked at costa and before anal angle, to which it is recurved and emits spurs to ends of veins $2,3,4$; on the onter side of median line between veins 2 and 5 a brown triangle is subtended outwards, meeting two branches emitted inwards from the onter line; an irregular fine submarginal line from costa to middle of wing; veins thickened and darkened at their extremities; the reticulations pale brown; fringe ochraceous with a dark line at base.

Hindwing: with the two onter lines repeated.

Underside pale silky yellow, with only the darker lines faintly represented.

Head, thorax, and abdomen mixed dark and light ochraceons.

Expanse of wings : $\delta 27 \mathrm{~mm}$. ; \& $32 \mathrm{~mm}$.

$2 \delta \delta, 1 q$ from Biagi, Mambaré River, British New Guinea, $5000 \mathrm{ft}$., April 1906 (A. S. Meek).

\section{Plesiodesma gen. nov.}

§. Forewing: triangular; costa straight, slightly incurved bejond middle and convex before apex; outer margin curved.

Hindwing: with outer margin and both angles rounded.

Antennae strongly serrate, and with fascicles of cilia; palpi minute, pointed; tongue absent; abdomen with the sheaths of anal segment large.

Neuration : forewing, cell half as long as wing; vein 2 from one-half, 3 just before end of cell, 4 and 5 long-stalked, 6 from the depressed end of cell; 7, 8 


\section{$(346)$}

long-stalked, widely divergent, shortly stalked with $9 ; 10,11$ free: hindwing, 7 from before end of cell, 4 and 5 stalked.

Type: Plesiodesma infans spec. nov.

\section{Plesiodesma infans spec. nov.}

Forewing: brownish fuscons, covered with minnte annuliform ochreous reticulations, which form obscure antemedian, postmedian, and submarginal bands; fringe brown, with the base ochreous yellow.

Hindwing : similar.

Underside the same.

Head, thorax, and abdomen varied with brown and ochreous; anal parts, antennae and abdomen beneath ochreons; vertex whitish.

Expanse of wings : $16 \mathrm{~mm}$.

$1 \delta$ from Kumusi River, N.E. British New Gninea, low elevation, May 1907 (A. S. Meek).

\section{Proterozeuxis brunnea spec. nov.}

Forewing: dark brown, slightly paler in $q$, densely covered with deeper transverse reticnlating striae and with irregnlar darker lines ; four vertical before middle, varying mnch even in the wings of the same specimen; a postmedian line forked at costa and with a slightly browner clond at end of cell, where it again divides, one branch running to inner margin and there forked, the other to anal angle; a submarginal line from costa to outer margin below middle; fringe dark brown, paler at apex.

Hindwing: with the last three lines of forewing reproduced.

Underside paler ; the lines more distinct, the reticnlations reduced.

Head, thorax, and abdomen like wings.

Expanse of wings : ठ $48-50 \mathrm{~mm}$; $\uparrow 54 \mathrm{~mm}$.

2 ठิ ठै, 1 \&, from Shilouvane, Transvaal, November-December 1901 (H. Junod).

This is nearest Rhodoneura pectinifera Hmpsn., from Sierra Leone.

\section{Proterozeuxis tessellata spec. nov.}

Forewing: whitish ochreous, thickly reticulated with dark brown and with darker brown interlacing lines, which start from brown triangular costal spots; two near base, more vertical ; those beyond ontwardly obliqne at first; two above end of cell unite at the black discal spot, then diverge, to unite again on submedian fold, and fork to inner margin; the fifth runs irregularly to anal angle, where it forks and is connected thronghout by ramifying streaks with the preceding line and also with the sixth, which is forked at costa and runs to middle of outer margin; fringe deep brown with paler apices ; veins brown.

Hindwing: with the three onter lines; the black discal spot with one of the lines forms a kind of ocellus.

Underside the same.

Head, shoulders, and dorsum dark brown; patagia paler brown, much varied with ochreous white scales; abdomen beneath with pairs of large shining whitish spots at the end of each segment and traces of lateral ones.

Expanse of wings : $40 \mathrm{~mm}$.

Two of from Kasangazi, near Bandawe, $3000 \mathrm{ft}$. above Lake Nyassa, (Dr. Prentice), 
62. Rhodoneura erubrescens spec. nov.

Forewing: chalk-grey; the costa brownish for two-thirds, finely striated with dark; a diffuse brownish grey shade at base, running out along lower half of cell and below it to between the origin of the median nervnles; the whole wing thickly covered with wavy brown-grey striae between the veins, which are fiuer and sometimes obsolescent towards apex; all the veins except the subcostal and costal deep pink; a slight grey costal mark in the pale space beyond the costal streak ; traces of inner, postmedian, and submarginal lines visible on inner margin ; fringe deep pink.

Hindwing: suffused with brown beyond middle, the basal area white with few strigae except close to base; the strigae in outer half thickened, fuscous tinged with red, forming dark waved lines alternating with finer ones; veins all pink; fringe deep pink, white along inner margin and at anal angle.

Underside of forewing with five olive-fulvous transverse markings: the antemedian swollen, the median curved and interrupted; the postmedian longer; and two conjoined towards anal angle: costal streak towards apex olive-fulvous with black spots ; apical area dull silvery with the veins bright red; a bed of black and yellow scales along lower half of cell and the base of veins $6,7,8$ finely black; fringe deep pink; hindwing white with all the transverse streaks as well as the veins and fringe bright pink.

Head and prothorax dull brown-grey ; tips of patagia and abdomen whitish, the dorsum with slight grey bands.

Expanse of wings : $38 \mathrm{~mm}$.

Two $f q$ from the Khasias (type); one $q$ from Maymyo, Shan States, June to Angust, 1902 (Hauxwell).

This seems to me to be quite distinct from the Chinese strigatula, which has no red whatever on the upper side, and the fringe whitish.

\section{Rhodoneura pudicula ab. obsolescens nov.}

In this form, which appears to be as widely spread as Guenée's type-form, the brown spots and blotches in both wings are attenuated and partially obsolescent, the apical half of forewing above vein 4 being entirely without markings.

In the Tring Museum there are five specimens : 1 from Java ; $30 \delta$ from Engano, and $1 \delta$ from Humboldt Bay, New Guinea (type); all five are slightly larger than average examples.

\section{Rhodoneura separata spec. nov.}

Forewing: white; the veins finely pinkish; costa with densely placed short dark striae; the costal vein dark brown; wing crossed by grey or grey-pink strigulations between the veins, much farther apart than in erubrescens and not forming lines, but sparse and irregular reticnlations ; a slight greyish shade in basal half of wing, beyond the oblique edge of which is an unreticulated whitish band as far as vein 6 ; fringe white.

Hindwing: purer white; strigulae brown and pink; a median band of two lines of striae below vein 5 , broken up above it; two irregular rows of submarginal striae, and a few at base ; the median band having a clear white space on each side of it; fringe white.

Underside with the veins and transverse strignlae deep pink ; costa of forewing 
fulvons ; the transverse fulvous bands, prominent in erubrescens, all but obsolete; a bed of black and yellow scales at base of cell and fine black scales along base of veins $6,7,8$.

Head, thorax, and abdomen as in erubrescens.

Expanse of wings : $30-36 \mathrm{~mm}$.

1 from Etna Bay, New Guinea, Angust 1896 (Webster) type ; 1 from Obi Major (Waterstradt).

\section{Siculodes intermedia spec. nov.}

Intermediate in size between S. sterna Feld. and S. paullula Pag., for, while the latter reaches $25 \mathrm{~mm}$. only, and sterna expands from $34 \mathrm{~mm}$. to $40 \mathrm{~mm}$., the present species measures $30-32 \mathrm{~mm}$. The three species can be well separated by a comparison of the undersides of the forewing. Thus in sterna the central area, which on the upper surface is pearl-grey, becomes yellowish beneath, and the veins are yellow, ehanging to reddish only just before margin; in paullula vein 7 is strongly and brilliantly red with a bed of lnstrous leaden-grey scales on each side of it, the other veins being faintly pink; in intermedia all the veins are uniformly pink throughout; secondly, the two patches in submedian interval and that before onter margin are diffusely fulvous in intermedia, in sterna the fulvous tints are hardly visible, while in paullula they are concise and deep chestnut-brown.

3 ठै $\delta$ from Santo Domingo, Carabaya, S.E. Pern, January to May 1902 (Ockenden).

\section{Siculodes nigralbata spec. nov.}

Forewing: chalk-white, with numerous grey spots between the veins and black streaks along the margins; a black spot at base of costa and four black streaks from costa to median vein, the first pair outwardly, the second inwardly oblique, the fourth running on the discocellular; the grey spots alternate with black; before outer margin the two outermost rows of black spots coalesce laterally into blotches ; dull black blotches on margin at the vein-ends, with white black-dotted spots between them ; fringe worn, apparently mottled black and white.

Hindwing: with the black spots and streaks amplified, those along onter margin forming a kind of festoon, with the margin itself clondy black.

Underside like upper; the base of forewing with shining silvery scales; basal half of cell and the subcostal and adjoining veins tinged with yellow.

Head, shoulders, and basal half of patagia blackish grey, mixed with white scales; thorax, apical half of patagia, and basal half of dorsum white, the last with two black spots at base and a broad black belt at one-fourth; anal half of dorsum black with narrow white segmental rings ; abdomen beneath and legs white ; tarsi black, white at the joints.

Expanse of wings : $24 \mathrm{~mm}$.

1 o from Kumusi River, N.E. British New Guinea, low elevation, AngustSeptember 1907 (A. S. Meek).

\section{Siculodes roseobrunnea spec. nov.}

Forewing: white with an iridescent violet sheen, crossed by series of oblique rosy and brown lines, the colours varying according to the incidence of light; 
costa with seven or eight olive-brown patches, from the sides of which the lines rise in pairs ; from the fifth, which is largest, the lines are darker and thicker and form a central band, followed by a paler band of the ground colour, edged externally by a dull rosy line running to below apex, the marginal area beyond it darkened by thicker and denser reticulations ; a slight dark flush along middle of wing between veins 2 and 5 , so that the costal and inner-marginal areas appear paler; veins towards margin finely brown; fringe rosy brown.

Hindwing: with a series of irregular striated lines parallel to outer margin, thickening towards inner margin and there becoming browner, the dark and pale bands of forewing hardly visible; costa cream-colour, with slight markings; marginal line rosy; fringe rosy whitish.

Underside of forewing suffused with olive-brown, deepest along costa, the markings visible only along inner and onter margin, where the lines are rosy tinged; a patch of deep black scales in and below basal halt of cell, and a few linear black marks along its upper edge at the end; hindwing with veins and markings bright rosy, only the costal area tingel with brown.

Head, shoulders, and antennae olive-brown ; thorax and patagia cream-colour; abdomen cream-colour, with the dorsum tinged with pale olive, and with some lateral rosy markings.

Expanse of wings : $28 \mathrm{~mm}$.

$1 \delta$ from St. Domingo, Carabaya, S.E. Peru, 6000 ft., Jannary 1902, wet season (Ockenden).

\section{Siculodes stigmatophora spec. nov.}

Forewing: dull white, with numerons grey reticulations, which in basal twothirds are somewhat dimmed by a pale grey suffusion; they rise from six pairs of darker grey lines on costa forming slight grey blotches, three before and three beyoud the middle, each marked on the extreme costal edge by a fine black line; a large black cell-spot on discocellular; the reticulations along onter margin are clearer and more fuscous, and are separated from the greyer basal two-thirds by a broad submarginal whiter band which is comparatively unreticnlated except at costa ; fringe white with grey basal mottling beyond the veins.

Hindwing: with a median slightly grey-tinged band of three or four waved and interlacing lines containing on its inner edge a largish black cell-spot, preceded by a band of unreticulated white beyond two blackish basal lines; outer white band and marginal reticulations as in forewing.

Underside with the grey costal blotches of forewing distinct; all the grey mottlings darker, especially two blotches towards outer margin lying on the two folds; hindwing whiter, with the reticulations less marked; in forewing the base of cell is filled with black and white shining scales, and lines of similar smaller scales precede and follow the upper part of discocellular.

Head, shoulders, and thorax dark grey; patagia, abdomen above and below, and the legs white; tarsi spotted with black; the forelegs, like the palpi, externally grey.

Expanse of wings : $44 \mathrm{~mm}$.

1 from La Union, R. Hnacamayo, Carabaya, Pern, 2000 ft., December 1904, wet season (Ockenden). 
69. Siculodes subolivescens spec. nov.

ठ. Forewing: shining iridescent hyaline white, uniformly covered with olivefuscons reticulations ; costal streak broadly grey-brown, bronzy red towards apex ; a dark inwardly oblique line on discocellular; a fine olive marginal line; fringe white with slight olive mottling beyond veins.

Hindwing: similar, but without the dark costa.

Underside with the costa of forewing broadly, of hindwing slightly bronzy olive; the reticnlations mainly showing through from above; marginal line reddish.

$f$ with stronger iridescence; the reticnlations olive; the costa of forewing marked with eight or nine patches of bronzy reddish ; the discocellular line, two patches on vein 1, and a submarginal patch beyond cell reddish olive; fringe mottled with rosy pink.

Underside with the marginal lines and mottlings of fringe bright rose-pink.

Head, shonlders, and base of patagia greyish olive; rest of patagia and thorax white; dorsum white, with the basal half of each segmentolive; forelegs olivebrown. The tarsi black with white joints; hindlegs reddish; abdomen beneath white.

Expanse of wings : $\delta 45 \mathrm{~mm}$; $\uparrow 52 \mathrm{~mm}$.

A pair from Agualani, Carabaya, Peru, 9000 feet, July, Angust 1905, dry season (Ockenden).

70. Siculodes viriditincta spec. nov.

Forewing: dull white, without any iridescence or hyaline spaces; the reticnlating lines rather thick and dnll olive; the median nervure and veins 1 to 4 all olive-fuscons; a dull olive subcostal streak; the costal edge pale with dense and sharp olive striae; a small dark spot at lower end of discocellular, and dark spots at the ends of the veins in the pale fringe; space between two oblique lines in the lower half of submedian interspace at middle of wing filled in with pale olive.

Hindwing: with all the lines more or less parallel to outer margin; the base with few reticulations.

Underside with a slight olive suffusion; the reticulations as above; streaks of black and yellow scales in base of cell and along its upper margin towards end.

Head, shonlders, and thorax olive; metathorax, tips of patagia, and two basal segments of dorsum white; rest of dorsum white tinged with olive; abdomen beneath and legs whitish; fore-tarsi black with pale joints.

Expanse of wings : $45 \mathrm{~mm}$.

1 from Paramba, Ecuador, November and December, 1898.

71. Striglina jucunda spee. nov.

Forewing: brown, with a bright reddish suffusion, obscuring the markings except along costa and outer margin ; these markings consist of small yellow round spots between the veins; the costa is, marked with large yellow spots in pairs with a third between them on the subcostal vein; from the first pair at two-fifths a slight curved red-tinged line runs to one-third of inner margin; from the second pair at two-thirds and from a single spot beyond them a forked yellow line rises, running straight across wing to inner margin at two-thirds parallel to onter margin, which below the middle is tinged with red; the apex and onter marginal area are dusted 
with round yellow dots and spots, a larger one between veins 4 and 5 ; fringe evenly mottled brown and yellow.

Hindwing: with the red suffusing only the basal half, which is bonnded by an irregular serpentine yellow streak, which throws off two similar streaks to onter margin below middle, the lower one interrupted; outer half full of yellow spots and dots.

Underside liver-brown withont any red tinge, and with the yellow dots and dusting largely developed, the onter line wholly yellow, with the brown beyond it less interrupted.

Head and shonlders yellow varied with pale and dark brown and black; the shonlders most clearly yellow ; thorax and abdomen brown mixed with red; legs black and yellow.

Expanse of wings : $28 \mathrm{~mm}$.

2 ठ ठ from La Oroya, R. Inambari, $3100 \mathrm{ft}$., January 1906, wet season (Ockenden); and $2 \delta$ of from Fonte Boa, Upper Amazons, July 1906 (Klages).

\section{THE BIRDS OF VELLA LAVELLA, SOLOMON ISLANDS.}

By the HON. Walter rothischild, Рh.D., and ERnst hartert, Рh.D.

\section{(Plate XIII.)}

THE island of Vella Lavella is one of the central group of Solomon Islands, to which belong the islands New Georgia or Rubiana, Rendova, Kulambangra, and Gizo. We have already had collections from Gizo, Kulambangra, Rendova, and New Georgia, all brought together by Mr. Albert S. Meek, who has now visited Vella Lavella. This last island is close to Gizo and Kulambangra. As no bird has ever been collected before on Vella Lavella, a collection from there is a priori of great interest. Moreover, while the majority of the species are, of course, identical with those from the other islands of the central group, some most interesting new forms have been discovered by our indefatigable collector, Albert Meek. In Noritates Zoologicae 1905, pp. 243, 244, we have explained that the central group of the Solomon Islands can be regarded as a faunistic area difierent from the northern chain (Bongainville, Choiseul, Isabel) as well as from the Guadalcanar group, and the sonthern group (San Christoval and Ugi).

An interesting feature of the birds of Vella Lavella is the fact that the forms peculiar to that island show a tendency towards a melanistic coloration. Myzomela eichhorni atrata has the upper surface black instead of dark olive as in M. eichhorni eichhorni; Pachycephala melanonota is above deep black instead of yellowish olive as in P. astrolabi; Monarcha brodiei nigrotectus has the upper wing-coverts blueblack instead of white.

The ornis of the island of Ronongo, close to Vella Lavella, remains to be explored, but not many new forms can be expected from there.

\section{Megapodius duperreyii eremita Hartl.}

Cf. Nov. Zool. 1905, p. 244.

3 ठठ $\delta$ ad., 2 if ad., 1 ठ pull., Vella Lavella, February and March 1908. Nos. 3\%91, 3806, 38\%0, 3883, 3909, 3928. 


\section{$2 \mathrm{BHL}$ Biodiversity Heritage Library}

Warren, William. 1908. "New Thyrididae in the Tring Museum." Novitates zoologicae : a journal of zoology in connection with the Tring Museum 15, 325-351. https://doi.org/10.5962/bhl.part.15475.

View This Item Online: https://www.biodiversitylibrary.org/item/21970

DOI: https://doi.org/10.5962/bhl.part.15475

Permalink: https://www.biodiversitylibrary.org/partpdf/15475

\section{Holding Institution}

Natural History Museum Library, London

\section{Sponsored by}

Natural History Museum Library, London

\section{Copyright \& Reuse}

Copyright Status: Public domain. The BHL considers that this work is no longer under copyright protection.

This document was created from content at the Biodiversity Heritage Library, the world's largest open access digital library for biodiversity literature and archives. Visit BHL at https://www.biodiversitylibrary.org. 